\title{
EFFECT OF EXPERIMENTAL DEVASCULARIZATION ON PERIPHERAL NERVES
}

\author{
Eros Abrantes Erhart* \\ CecIL José Rezze***
}

Recently while reporting before the VIII International Congress of Anatomists, Wiesbaden, Germany and the V International Congress of Neuropathology, Zurich, Switzerland, we mentioned the functional importance of the vasa-nervorum and nerve natural connective tissue bed during the nerve regeneration (Erhart and Rezze ${ }^{11}$ ). In this paper our experimental observation on the subject is presented and discussed in detail.

It is known that functioning of peripheral nerves is influenced by the vascular supply and that cessation of the blood supply to any part of a nerve affect the passage of the nerve impulse and therefore ultimately induce a nerve block (Mayer ${ }^{15}$, Lapinsky ${ }^{13}$, Okada ${ }^{16}$, Barker ${ }^{5}$, Lewis and Pochin ${ }^{14}$, Auersperg et $a l .^{3}$, Erhart ${ }^{9}$, Sahs ${ }^{19}$ and many others). Nevertheless, surgeons in general, while performing nerve sutures seem either to ignore completely the fine vascularity of the nerves or to regard it as a factor of no real consequence. Therefore, the main purpose of this paper is to demonstrate to what an extent a nerve can be damage when its blood supply, beautifully illustrated by Lang ${ }^{12}$, is partially compromised during a nerve suture by a vicious manipulation.

\section{MATERIAL AND METHODS}

Nerve devascularizations were performed, under general anesthesia on the upper right arm of ten adult mongrel dogs. A Zeiss dissecting microscope $(\times 10)$ was used in order to injure 4 to $5 \mathrm{~cm}$ of the ulnar and median nerves vascularization including the correspondent connective tissue beds.

One month after the devascularization the operative field and the main muscular territories innervated by the injured nerves were exposed under anesthesia. Before excising the nerves for histopathological study, their functional integrity was electrically and mechanically tested by the usual methods.

\section{RESULTS}

The experimental nerve devascularization determined in all dogs, thirty days after the standard operation, motor deficiencies which were more evident in some muscular groups than in others.

Departamento de Anatomia da Faculdade de Medicina da Universidade de São Paulo (Prof. O. Machado de Sousa): * Professor Assistente, Docente-Livre, Chefe da Secção de Neuranatomia; ** Professor Assistente. 
The histological serial nerve preparations (De Castro silver impregnation, $H$. \& E., Masson and Pal-Weigert modified by Erhart for myelin sheaths) showed distad nerve degeneration, which was total in some fascicles and partial in others, and characteristic connective tissue proliferation (Figs. 1, 2, 3, 4).
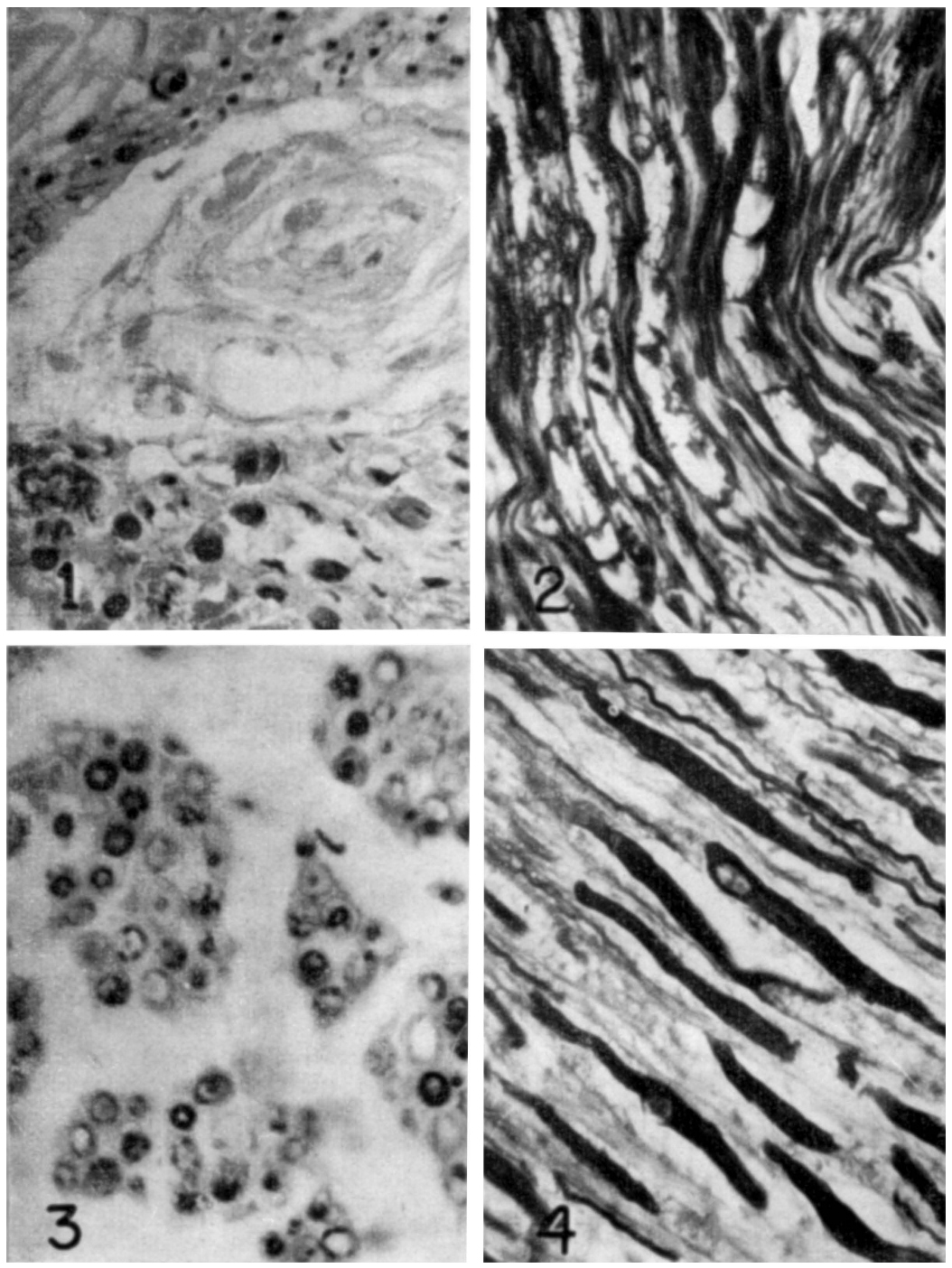

Photomicrographs of dog nerves thirty days after experimental devascularization. Fig. 1 - Nerve fascicle with extensive degenerative area. Trans. section, De Castro $(\times 900)$. Fig. $2-$ Nerve fibres surrounded by intense connective tissue proliferation. Longt. section, Masson $(\times 900)$. Fig. 3 - Nerve fibres showing degeneration of their myelin sheaths. Trans. section, Pal-Weigert modified by Erhart $(\times 900)$. Fig. 4 - Nerve fibres in degeneration. Longt. section, De Castro $(\times 900)$. 


\section{DISCUSSION}

The anatomical evidence clearly demonstrates that the regional blood supply of nerves is generally superimposed by an extensive longitudinal arterial pathway which accompanies the nerve throughout its length (Adams ${ }^{1,2}$, Blunt ${ }^{6}$, Lang ${ }^{12}$, Sousa ${ }^{20}$ and others). Therefore, the arterial anastomosis within the nerve play a responsible part in maintaining the integrity of a normally functioning nerve.

The earliest available account of investigation of a nerve after devascularization seems to be that of Mayer ${ }^{15}$, who found that the devascularized facial nerve in situ, in the rabbit, lost its excitability in 15 to 30 minutes. Many other experiments were carried out in this line with equivalent results which indicated that local ischaemia produces significant effects on the transmission of the nerve impulse. However, these changes are generally considered reversible, because the longitudinal vascular pathway may provide a collateral circulation to the nerve and restore its capacity to conduct. Unless the longitudinal anastomosis should be inadequate to accommodate itself to the changed conditions, there is little reason to expect degeneration of nerve fibres. But, prolonged local ischaemia might result in a severe destruction of a nerve tissue.

An infarction of the nerve may occur when the regional vascular sources of a nerve are abolished and, at the same time, the continuity of the longitudinal pathway is interrupted. Barker ${ }^{5}$, for example, found that occlusion of the vasa-nervorum - arteries and veins - was associated with degenerative changes in nerves. Denny-Brown and Brenner 8 reported patchy swelling of the axis-cylinders with vacuolation of the myelin. But other authors as Adams ${ }^{2}$, Bacsich and Wyburn ${ }^{4}$ and Roberts ${ }^{18}$ obtained results of a relatively negative character. Their histological nerve preparations showed no degeneration whatever or, at the most, degeneration of relatively few solitary fibres. No connective tissue proliferation or other obvious histclogical changes were observed. Although supporting such a statement Adams ${ }^{2}$ reported that two of his experimental cases presented extensive degeneration with concomitant clinical signs. He attributed such results to the "slight manipulation of the nerve" or to some variation in its intrinsic vascular pattern.

We agree with him particularly at this point: a vicious manipulation of the nerve stumps during the nerve sutures or neurolisys damages to much the nerve vascularity which is essential for a good nerve regeneration. Richter ${ }^{17}$ considered the bad results of grafts due to vascular. deficiences and Weddell 21 states: "Nerve bundles which are more closely related to large blood vessels are more rapidly re-innervated than those farther away". Moreover, Erhart 10 observed that distal nerve segments, dislocated from their surrounding bed by accident or by intentional vicious manipulation, did not show structural integrity and nerve-fibre richness comparable to equivalent nerve segments which were kept in their connective bed. Also they required stronger electrical stimulus to produce muscular contraction, than those kept practically undisturbed in their original habitat. 
The motor deficiencies which were more evident in some muscular groups than in others, thirty days after the nerve devascularization, could be correlated to the total or partial nerve fascicle degenerative processes observed in the serial histological preparations. These larger or lesser nerve degenerative processes, determined by experimental prolonged local ischaemia, were most probably due to the individual vascular variation in its intrinsic pattern, since our operative procedure has been the same in all dogs.

Concluding we may state, based on the results of the present investigation, that the nerve vascularity and the surrounding bed - connective tissue rich in plasma and in capillaries, the "millieu" of Cajal ${ }^{7}$ - are of vital importance to maintain the nerve, as well as to allow the regenerative process. Therefore, it must be emphasized that during nerve suture, the nerve segments should be kept as much as possible undisturbed in their connective beds, in order to avoid nutritional deficiencies which would difficult the regeneration of the nerve.

\section{SUMMARY}

In order to explore the functional importance of the vasa-nervorum and the nerve natural connective bed, fine nerve devascularizations were performed in ten adult dogs, using a dissecting microscope. 4 to $5 \mathrm{~cm}$ of the nerve vascularization and corresponding connective bed were injured. By this procedure it could be demonstrated, 30 days later, motor deficiencies and in the histological serial preparations a distad nerve degeneration, total in some fascicles and partial in others.

\section{RESUMO}

\section{Efeitos de desvascularização experimental em nervos periféricos}

Em publicaçōes anteriores nos referimos à importância funcional dos "vasa-nervorum" e do leito conectivo natural de nervos nos processos de degeneração e regeneração nervosa periférica. Neste trabalho são apresentados e discutidos os resultados de desvascularizações experimentais efetuadas sob anestesia e cuidados assépticos de rotina, em nervos ulnar e mediano de 10 cães, no têrço superior do braço.

Utilizando microscópio cirúrgico $(\times 10)$ e instrumental apropriado foram lesados, ao longo de cada nervo, 4 a $5 \mathrm{~cm}$ de sua fina vascularização e correspondente leito conectivo. Trinta dias após a operação pôde-se constatar em todos os cães deficiências motoras, algumas bastante evidentes e outras discretas, em grupos musculares do antebraço, subordinados à inervação do ulnar e mediano. Os cortes histológicos seriados comprovaram essas observações, visto que, demonstraram existir distalmente à região desvascularizada, degenerações totais ou parciais de fibras e fascículos nervosos. 
Em face dessas observações conclui-se que parte do bom êxito de neurorrafias e neurolises está na dependência direta do manuseio dos segmentos dos nervos. A fina vascularização e o leito conectivo natural do nervo devem ser sempre respeitados ao máximo, dentro das possibilidades e contingências de cada caso, visto serem estas estruturas indispensáveis à manutenção e eficaz regeneração de fibras nervosas periféricas.

\section{REFERENCES}

1. ADAMS, W. E. - The blood supply of nerves. Historical review. J. Anat. 76:323-341, 1942. 2. ADAMS, W. E. - The blood supply of nerves. The effects of exclusion of its regional sources of supply on the sciatic nerve of the rabbit. $J$. Anat. 77:243-250, 1943. 3. AUERSPERG, A.; AIDAR, O. \& ERHART, E. A. - Disturbances of sensation occasioned by experimental arrest of blood flow. Arq. Neuropsiquiat. (S. Paulo) $7: 371-392,1949$. 4. BACSICH, P. \& WYBURN, G. M. - The effect of interference with the blood supply on the regeneration of peripheral nerves. J. Anat. 79:74-82, 1945. 5. BARKER, N. W. - 1938 (cited by Adams ${ }^{2}$ ). 6. BLUNT, M. J. - The vascular anatomy of the median nerve in the forearm and hand. J. Anat. 93:15-22, 1959. 7. CAJAL, S. RAMON y - Degeneration and regeneration of the nervous system. Translated and eait. by Raoul M. May. Oxford Univ. Press, London, 1928. 8. DENNY-BROWN, D. \& BRENNER, C. - Paralysis of nerve induced by direct pressure and by tourniquet. Arch. Neurol. Psychiat. 51:1-26, 1944. 9. ERHART, E. A. - Nerve compression as an essential factor in causing ischaemic and post-ischaemic paraesthesiae. Arq. Neuro-psiquiat. (S. Paulo) 8:39-42, 1950. 10. ERHART, E. A. - Normal nerve-fibres in the distal segment of nerves completely separated from the proximal stump for more than six months. Arq. Neuropsiquiat. (S. Paulo) 20:289-306, 1962. 11. ERHART, E. A. \& REZZE, J. C. - Experimental data and practical results which modify the present concepts of peripheral nerve fibres degeneration and regeneration. Proceedings of the $\mathrm{V}$ International Congress of Neuropathology :667-671, 1965. Published by the Excerpta Medica. 12. LANG, J. - Uber das Bindegewebe und die Gefässe der Nerven. Zeit. f. Anat. 123: 61-79, 1962. 13. LAPINSKY, M. - 1899 (cited by Adams ${ }^{2}$ ). 14. LEWIS, Th. \& POCHIN, E. - Effects of asphyxia and pressure on sensory nerves of man. Clin. Sc. 3:141-155, 1938. 15. MAYER, S. - 1878 (cited by Adams ${ }^{2}$ ). 16. OKADA, E. Experimentelle Untersuchungen über die vasculäre Trophik des peripheren Nerven. Arb. neurol. Inst. 12:59-85, 1905. 17. RICHTER, G. A. - 1952. In Gutmann, E. - Die funktionelle Regeneration der peripheren Nerven. Akademie Verlag, Berlin, 1958. 18. ROBERTS, J. T. - The effect of occlusive arterial diseases of the extremities on the blood supply of nerves. Experimental and clinical studies on the role of the vasa nervorum. Am. Heart J. 35:369-392, 1948. 19. SAHS, A. L. Extracerebral neurovascular disease. Arch. Neurol. 6:87-95, 1962. 20. SOUSA, O. MACHADO de - Contribution à l'étude de la vascularisation du systeme nerveux organo-végétative. Ann. Anat. Pathol. 9:975-997, 1932. 21. WEDDELL, J. - Axonal regeneration in cutaneous nerve plexuses. J. Anat. 77:49-62, 1942.

Departamento de Anatomia - Faculdade de Medicina da Universidade de São Paulo - Caixa Postal 2921 - São Paulo, SP — Brasil. 